\title{
Monipuolisen ja -muotoisen tieteellisen julkaisutoiminnan puolesta
}

\author{
Viidenkymmenen kahden tieteellisen seuran kannanotto \\ tieteellisen julkaisutoiminnan arviointisuunnitelmiin
}

Eduskunnan sivistysvaliokunta

Opetus- ja kulttuuriministeriö

Suomen Akatemia

Suomen yliopistot UNIFI ry

Suomen yliopistojen rehtorit

Tieteellisten seurain valtuuskunta ja

Julkaisufoorumihanke

SUOMEN YLIOPISTOJÄRJESTELMÄÄ on uudistettu merkittävästi. Uudistuksen ytimeen nostettu arviointikulttuuri on sitoutunut liian vahvasti hallinnolliseen ja määrälliseen tulosajatteluun ja siihen läheisesti liittyvään ranking-tarkasteluun. Näiden vaikutukset yliopistojen todellisuudessa näyttävät jo nyt ohjaavan toimintaa monella tasolla epätoivottavaan suuntaan. Julkaisujen arviointi- ja pisteytysjärjestelmäksi tarkoitettu Julkaisufoorumihanke sisältää hyvistä tarkoitusperistä huolimatta myös piirteitä, joita emme eri tieteenalojen edustajina pidä tarkoituksenmukaisina.

Olemme erityisen huolestuneita kahdesta laajasta ongelmakokonaisuudesta, joista ensimmäinen on periaatteellinen ja jälkimmäinen käytännöllinen:

1) Julkaisujen arvioinnin välineellinen ja massamittainen järjestelmä on jäykkä eikä sen avulla kyetä juuri ottamaan huomioon tieteen- ja tutkimusalojen eroja, mikä kyseenalaistaa vakavasti koko arvioinnin mielekkyyden ja kestävyyden.

2) Julkaisufoorumihankkeen tulokset heijastuvat ja niitä voidaan käyttää - käytetään jo nyt - muihin kuin alkuperäisiin tarkoituksiinsa, mikä voi vaikuttaa huomattavan kielteisesti tieteenharjoittamisen tulevaisuuteen.

\section{JULKAISUFOORUMIHANKKEEN TOTEUTTAMAN ARVIOINNIN MIELEKKYYS JA KESTÄVYYS}

Tieteellisten julkaisujen arviointi on ollut aina keskeisellä sijalla tieteellisessä toiminnassa. Vertaisarviointi ja muu tutkimuksen laadun kontrollointi on kiinteä osa tieteellistä perustyötä. Ongelmalliseksi arviointi muuttuu, jos sitä ryhdytään harjoittamaan hallinnollisista syistä ja sille kehitetään tieteellisen toiminnan ulkopuolelta välineellistä, massamittaista 
ja yhdenmukaista järjestelmää.

On hankalaa, tiukasti ajatellen jopa mahdotonta, verrata keskenään perustavanlaatuisesti erilaisten tieteenalojen julkaisukäytäntöjä. Lausunnon allekirjoittaneita tieteellisiä seuroja huolestuttaa erityisesti se, ettei Julkaisufoorumihankkeen esittämissä arviointikriteereissä ole otettu huomioon tieteenalojen - ja tiettyjen tieteenalojen osa-alueiden - erilaisia julkaisuperinteitä ja -kanavia riittävästi. On selvää, että tiedehallinnossa ja korkeakoulupolitiikassa tarvitaan arviointikeinoja. Uusia arvioinnin käytäntöjä luotaessa tulisi kuitenkin tuoda näkyviin myös niiden kääntöpuoli, varaukset ja rajoitukset selvemmin kuin Julkaisufoorumihankkeessa on tähän asti tehty.

Toisekseen on kyseenalaista, voidaanko eri tieteenalojen kotimaisia ja kansainvälisiä julkaisuja verrata toisiinsa lainkaan. Kotimaisella ja kansainvälisellä julkaisemisella on molemmilla oma arvonsa ja tarkoituksensa. Julkaisufoorumihanketta ja vastaavia arviointimalleja hallitseva ajattelutapa on ilmeisesti peräisin enimmiltään luonnon-, lääke- ja teknisistä tieteistä esimerkiksi oikeus-, sosiaali-, kulttuuri- ja kasvatustieteiden sijaan. Tunnetusti ja tunnustetusti tieteenalat merkitsevät yhteiskunnalle ja kulttuurille eri asioita. Esimerkiksi luonnon- ja lääketieteet ovat kohteiltaan universaaleja ja enimmäkseen teknisesti sovellettuja. Sosiaali- ja kulttuuritieteiden anti on puolestaan riippuvainen niiden kiinteästä suhteesta kulttuuriseen ja kielelliseen ympäristöönsä: esimerkiksi sivistykseen, kulttuuriperintöön, koulutukseen, asiantuntijajärjestelmiin, julkiseen keskusteluun ja kansalaisyhteiskuntaan sekä hallintoon. Tieteenalojen erilaisuus näkyy myös niiden historiassa ja käytännöissä. Se käy ilmi myös tilastoista: esimerkiksi sosiaali- ja kulttuuritieteiden julkaisuista yli 50 prosenttia on kotimaisia, mutta esimerkiksi perusluonnontieteissä ja lääketieteissä julkaistaan lähes sataprosenttisesti kansainvälisesti, käytännössä englanniksi. Eroilla on perustellut syynsä, ne syntyvät jo sekä tutkimuskohteiden että tutkimusaineistojen olemuksellisesta erilaisuudesta ja päätyvät aina näiden tieteenalojen yhteiskunnallisen vaikuttavuuden erilaiseen luonteeseen.
Tällä hetkellä Julkaisufoorumihankkeessa tämä perustavanlaatuinen erilaisuus ei näy likimainkaan riittävästi. Siinä korostuu hyvin yksipuolisesti ulkomaisen, etenkin englanninkielisen, julkaisemisen merkitys. Myöskään nähdäksemme julkaisufoorumissakin yhtenä arvioinnin perustana käytetyt julkaisujen impact factor -indeksit eivät ole kovin kattavia indeksejä, kun puhutaan julkaisujen laadusta ja arvioidaan niiden merkittävyyttä. Myös se, että erittäin suuri osa kakkos- ja kolmoskategoriaan päässeistä julkaisuista on englanninkielisiä, kertoo selkeästi tämänkaltaisen arvioinnin kohtaamista vaikeuksista ja vinoutuneisuudesta. Tuskin on mahdollista, että kaikkien maailman tieteenalojen laatulehdistä vain muutama prosentti tulee englanninkielisen alueen ulkopuolelta.

\section{JULKAISUFOORUMIN ESITTÄMÄN ARVIOINTIJÄRJESTELMÄN NEGATIIVISET KÄYTÄNNÖN VAIKUTUKSET TIETEELLISEEN JULKAISUKULTTUURIIN}

Nyt suunnitellulla arviointimallilla on hyvin todennäköisesti ei-suunniteltuja ja ei-toivottuja vaikutuksia tiedejulkaisemiseen ja laajemminkin tutkimuksen suuntautumiseen. Julkaisufoorumihankkeen piirissä ei ole mielestämme arvioitu riittävän vakavasti näitä mahdollisia seurausvaikutuksia:

- Valittu arviointimalli ja -strategia tuskin kohtelevat kaikkia tieteenaloja ja tutkimussuuntauksia oikeudenmukaisesti ja tasapuolisesti. On suuri riski, että tulevaisuudessa tutkimus ja julkaiseminen ohjautuvat merkittävästi näin rakennettujen mittarien suosimille tutkimusalueille. Myös julkaiseminen voi keskittyä hyvin vahvasti tiettyihin kategorisoinnin etusijalle nostamiin julkaisuihin. Vahvana ohjauselementtinä tämä voi vääristää merkittävästi ja ei-tarkoituksenmukaisesti Suomessa tehtävää tutkimusta ja tutkimustulosten julkaisemista.

- Julkaisujen kategorisointiin perustuva arviointi tukee liiaksi jo olemassa olevia julkaisurakenteita ja -käytänteitä. Tämä vie mahdollisuuksia uusilta avauksilta ja innovatiivisilta julkaisumuodoilta, 
vaikka se olisi tutkimuksen edistymiselle ja uudistumiselle elintärkeää. Esimerkiksi tällä hetkellä nopeasti kehittyvät avoimen julkaisemisen (Open access) julkaisufoorumit ja -käytännöt voivat jäädä kokonaan huomiotta.

- Julkaisujen kategorisointi tukee kärkeen nostettujen lehtien ja kustantajien aseman monopolisoitumista, mikä ei ole suotava kehityssuunta. Jo nykyisellään tiedetään lukuisia negatiivisia tahattomia seurauksia, joita englanninkielisten journaalien ja julkaisusarjojen ylikorostuneella välineellisellä arvostuksella on ollut muun muassa julkaisujen hinnoittelussa, julkaisufoorumien tukkeutumisessa ja julkaisuprosessien pitkittymisessä.

- Julkaisufoorumihankkeen ohjaama julkaisupolitiikka ajaa kansallisen tieteellisen julkaisemisen ja tiedekustantamisen hankalaan asemaan. Kuitenkin monilla sosiaali-, kulttuuri- ja kasvatustieteellisillä aloilla kotimainen tiedejulkaiseminen on tutkimuksen edistymisen kannalta ensiarvoisen tärkeää. Tästä on syksyn 2011 aikana kannettu erityistä huolta eri alojen tiedejulkaisujen sivuilla. Allekirjoittajina jaamme saman huolen.

Yliopistojen rahoitusmalliehdotuksessa on jo rakennettu erittäin voimakas jako kansainväliseen ja kotimaiseen julkaisemiseen edellisen eduksi yli kolminkertaisessa suhteessa (ehdotuksen rahoituspainoarvot $10 \%$ ja $3 \%$ ). Kotimaisen julkaisemisen arvostuksen heikentämiselle tällä tavalla ja tässä laajuudessa ei löydy mitään perusteita. Rahoitusmalliehdotus esittää, että vastaava jako perustuisi vuodesta 2015 eteenpäin Julkaisufoorumihankkeen kategorioihin. Ellei kotimaisen julkaisemisen suurta merkitystä monilla tieteenaloilla ymmärretä, kotimaisen julkaisemisen aliarvostus jatkuu myös Julkaisufoorumihankkeen luokitteluissa.

Edistyäkseen ja pysyäkseen korkealla tasolla suomalainen tieteenharjoittaminen on aina tarvinnut sekä kotimaista että kansainvälistä julkaisemista. Niitä ei saa missään nimessä asettaa vastakkain, sillä molemmat ovat yhtälailla arvokkaita ja rikastuttavat toisiaan. Kansallinen julkaiseminen ei ole myöskään automaattisesti kansainvälistä julkaisemista heikompitasoista. Juuri tässä näkyy tieteenalojen erilaisuus: monilla aloilla kansallinen julkaisuseula on vähintään yhtä tiukka ja arviointi laadukkaampaakin kuin ulkomaisilla foorumeilla.

Edellä kuvatun kaltaisen politiikan epätoivottavia seurauksia tuskin voi kotimaisen julkaisemisen suhteen ylikorostaa. Käytännössä on suuri vaara, että kotimaiset julkaisut menettävät entisestään arvostustaan tutkimuspolitiikassa, vaikka näin ei saisi missään tapauksessa tapahtua. Suuntaus ei ole järkevää kansallista tiedepolitiikkaa eikä perusteltua kansainvälisenkään tiedepolitiikan näkökulmasta.

Tieteellisten julkaisujen arviointi on välttämätöntä ja julkaisutoiminnan kehittäminen erityisen tärkeää. Kuitenkin tässä kuten muussakin tutkimuksen kehittämisessä tulisi pitää tarkoin mielessä järki, oikeudenmukaisuus ja eri tieteen- ja tutkimusalojen historiallisesti muotoutuneet erilaiset lähtökohdat. On erittäin tärkeää, että tiedekentän ääniä kuullaan mahdollisimman laajasti ja avoimesti. Näinhän nyt ei ainakaan kaikilla tieteenaloilla ole tehty. Kun vaikutuksiltaan erittäin kauaskantoista julkaisufoorumien arviointijärjestelmää rakennetaan, hankkeesta pitäisi keskustella laaja-alaisesti ja avoimen kriittisesti. Tällaista keskustelua ei ole nyt ainakaan kaikilla tieteenaloilla käyty lainkaan. Tässä myös tieteentekijöiden kentän tulisi olla nykyistä aktiivisempi.

Muun muassa edellä esitettyjen syiden vuoksi olemme sitä mieltä, että tiedejulkaisujen arvioiminen ja arvottaminen nyt suunnitteilla olevalla tavalla on epäoikeudenmukainen ja että se ei täytä tarkoitustaan. Erityistä huolta meissä herättää se, että sekä ministeriössä että yliopistoissa suunnitellaan tältä pohjalta jo erilaisia linjauksia ja strategioita uudenlaiseen rahanjakoon.

Esitämme, että Julkaisufoorumihankkeelle annetaan lisää aikaa, jonka kuluessa haetaan avoimesti ja tasapuolisesti kestäviä sekä kaikkia toimija- ja tutkimustahoja tyydyttäviä käytänteitä julkaisujen arviointia varten. Sama vaatimus koskee ehdotusta yliopistojen rahoitusmalliksi, jonka karkeaa jakoa 
kansainvälisiin ja kotimaisiin julkaisuihin suuresti aiempaan verrattuna korostuvine rahoitusvaikutuksineen ei ehdotuksessa esitetyssä muodossa missään tapauksessa voida hyväksyä. Vasta kun kaikilla tasoilla - myös arvioinnin ja rahoituksen malleissa - arvostetaan julkaisukäytäntöjen tieteenaloittaista moninaisuutta, on mahdollista tukea laadukasta tieteellistä toimintaa.

Monipuolisen tieteellisen julkaisukulttuurin puolesta

Tammikuussa 26.1.2012

Aikuiskasvatuksen tutkimusseura

Alue- ja ympäristötutkimuksen seura ry

Eurooppalaisen filosofian seura (EFS ry)

Informaatiotutkimuksen yhdistys ITY r.y

Kansainvälisten suhteiden tutkimuksen seura ry.

Karl Marx-seura

Kasvun ja vanhenemisen tutkijat ry.

Klassillis-filologinen yhdistys r.y.

Korkeakoulututkimuksen seura (CHERIF)

Kotikielen Seura

Kulutuksentutkimuksen seura

Kulttuuritutkimuksen seura r.y.

Lapin Tutkimusseura

Lapsuudentutkimuksen seura

Luther-Agricola-Seura

Mediakasvatusseura ry

Nuorisotutkimusseura ry

Oikeuspoliittinen yhdistys Demla ry

Oikeus- ja yhteiskuntatieteellinen yhdistys

Oulun Historiaseura

Pohjois-Karjalan historiallinen yhdistys

Pohjois-Suomen maantieteellinen seura

Pohjoismaiden Maataloustutkijain Yhdistys, Suomen osasto NJF (Nordic Association of Agricultural Scientists)

Porthan-Seura

Rakennustaiteen Seura

Sosiaalilääketieteen yhdistys

Sosiaalityön tutkimuksen seura
Suomalaisen Kirjallisuuden Seura (SKS)

Suomen 1700-luvun tutkimuksen seura

Suomen ainedidaktinen tutkimusseura ry.

Suomen Eksegeettinen Seura

Suomen Estetiikan Seura

Suomen Etnomusikologinen seura

Suomen filosofian ja fenomenologisen tutkimuksen seura ry SFFS

Suomen kansatieteilijöiden yhdistys Ethnos ry

Suomen Kansantietouden Tutkijain Seura

Suomen kasvatustieteellinen seura ry.

Suomen keskiajan arkeologian seura

Suomen kielitieteellinen yhdistys SKY

Suomen kirkkohistoriallisen seura

Suomen Kouluhistoriallinen Seura ry

Suomen Musiikkitieteellinen Seura

Suomen Rauhantutkimusyhdistys (SRTY)

Suomen tieteellinen kirjastoseura

Suomen vammaistutkimuksen seura ry.

Taidehistorian seura - Föreningen för konsthistoria

Teatterintutkimuksen seura

Tiedotusopillinen yhdistys (TOY ry)

Tutkijaliitto

Valtiotieteellinen yhdistys ry.

Ympäristötieteellinen seura ry.

Westermarck-seura 